\title{
Factors Influencing Passengers' use of E-Hailing Services in Malaysia
}

\author{
Salman Salim, Mohamad Azim Mohammad Azmi, Mohd Erwan Sanik, Ahmad Hakimi Mat \\ Nor, Mohammad Hairi Osman
}

\begin{abstract}
The landscape of transportation services has changed for the better since the introduction of e-hailing companies. In general, e-hailing applications on smartphones can assist users in performing the following tasks; 1) locate taxis available; 2) allow drivers to identify passengers who require taxi services; 3) book a taxi; 4) allow drivers to receive taxi bookings; and 5) make payment online. It is easy to install e-hailing applications on any type of mobile device. Nevertheless, it is crucial to assess the efficiency of e-hailing applications as they are still new to the market. The efficiency of the system can be evaluated through the factor that contributed to the adoption of e-hailing. Thus, this study aims to investigate the factors that influence the passengers' towards the use of e-hailing services. The independent variables of this research are trustable, comfort, promotion and coupon redemption and fare; and the dependent variable is the passengers' perception. A survey was conducted among e-hailing users in Kuala Lumpur, the capital of Malaysia. With the use of a survey questionnaire, 107 targeted respondents provided valuable feedback. The surveys were carried out by boarding e-hailing passengers' on working days. Therefore, the respondent population corresponds to all types of e-hailing passengers' in the city. The survey consisted of two parts; the first part contains general questions about gender, age, ethnic, employment, gender and frequency of usage. The second part is the major part of the questionnaire which consists of travel attributes. In previous literature, most relevant studies show that factor that influences the passengers to use the e-hailing services were found to be trustable, comfort, promotion and coupon redemption and fare. Therefore, the questionnaire has been built according to those significant factors. The correlation analysis was used to identify the relationship between independent variables and dependent variable. Through the results obtained, the linear regression shows that the trustable, comfort, promotion, and coupon redemption and fare provided a positive significant association with the factor that influences the passengers'. Among the variables studied, comfort shows the most significant factor in
\end{abstract}

Revised Manuscript Received on February 19, 2020.

* Correspondence Author

Salman Salim*, Centre for Diploma Studies, Universiti Tun Hussein Onn Malaysia, Pagoh, Johor, Malaysia. Email: Salman@uthm.edu.my

Mohamad Azim Mohammad Azmi, Centre for Diploma Studies, Universiti Tun Hussein Onn Malaysia, Pagoh, Johor, Malaysia. Email: azim@uthm.edu.my

Mohd Erwan Sanik, Centre for Diploma Studies, Universiti Tun Hussein Onn Malaysia, Pagoh, Johor, Malaysia. Email: erwans@uthm.edu.my

Ahmad Hakimi Mat Nor, Centre for Diploma Studies, Universiti Tun Hussein Onn Malaysia, Pagoh, Johor, Malaysia. Email: ahakimi@uthm.edu.my

Mohammad Hairi Osman, Faculty of Engineering Technology, Universiti Tun Hussein Onn Malaysia, Pagoh, Johor, Malaysia. Email: mhairi@uthm.edu.my

(C) The Authors. Published by Blue Eyes Intelligence Engineering and Sciences Publication (BEIESP). This is an open access article under the CC BY-NC-ND license (http://creativecommons.org/licenses/by-nc-nd/4.0/)

passengers' satisfaction towards e-hailing services in Malaysia with Cronbach's Alpha of 0.892. In conclusion, this study shows some important information and provide benefits particularly to e-hailing services company to be more competitive in this industry by understanding the needs and concerns of passengers' when they adopt the e-hailing services.

Keywords: e-hailing, passengers' satisfaction, trustable, comfort, promotion and coupon redemption, fare.

\section{INTRODUCTION}

In the old days, the most straightforward way to catch a taxi is to hail a taxi on the street. Later on, call centers for taxi services were established. Today, people depend on their smartphones for a multitude of reasons. Therefore, it is both a practical and logical idea to use smartphone applications for hailing taxis. E-hailing applications are widely available on both Android and iOS phones [1].

These applications have become increasingly trendy because taxi drivers who are connected to e-hailing applications tend to be more reliable than normal taxi drivers who may choose not to pick passengers up during peak hours or charge unreasonable prices. In 2012, the launch of e-hailing applications in Malaysia was viewed as a solution for alleviating transportation problems in big cities.

The landscape of transportation services has changed for the better since the introduction of e-hailing companies. Drivers and passengers are now connected via technology and the drivers are better informed regarding their passengers' basic background information and preferred destination [2]. Although the introduction of e-hailing services has caused controversy, they have nonetheless proved to be both economical and dependable. Besides providing employment opportunities, e-hailing services are also available in areas where public transportation is less common.

In general, e-hailing applications on smartphones can assist users in performing the following tasks; 1 ) locate taxis available; 2) allow drivers to identify passengers who require taxi services; 3) book a taxi; 4) allow drivers to receive taxi bookings; and 5) make payment online [3]. It is easy to install e-hailing applications on any type of mobile device. As mobile devices become increasingly common, e-hailing applications such as Uber, Grab Taxi, and JomRides have been gaining popularity in Malaysia. The public transportation industry has also transformed after the introduction of E-hailing applications. It is now becoming faster and more convenient for individuals to gain access to public transport [4]. 
Factors Influencing Passengers' use of E-Hailing Services in Malaysia

Before, individuals needed to hail taxis from the streets or book a taxi through call centers. Nowadays, they can book a ride using their mobile device as long as they have an internet connection. Nevertheless, it is crucial to assess the efficiency of e-hailing applications as they are still new to the market [5-6]. The efficiency of the system can be evaluated through user satisfaction as well as user perception. Thus, this study aims to investigate the factor that influenced the passengers' towards the use of e-hailing services. Factors influencing passengers to use e-hailing services in their daily life were identified based on the independent variables where is trustable, comfort, promotion, and coupon redemption and fare; and the dependent variable is passengers' perception.

\section{METHODOLOGY}

A survey was conducted among e-hailing users in Kuala Lumpur, the capital of Malaysia, in order to investigate the factor influencing the used of e-hailing services. The surveys were carried out by boarding e-hailing passengers' on working days. Therefore, the respondent population corresponds to all types of e-hailing users in the city. The survey consisted of two parts; the first part contains general questions about gender, age, ethnic, employment, and frequency of usage. The second part is the major part of the questionnaire which consists of travel attributes. In the previous literature, most relevant studies show that the passengers' satisfaction were found to be trustable, comfort, promotion and coupon redemption and fare.

Each respondent was asked to rate their satisfaction with each item on a scale from 1 to 10 ; where 1 is least satisfied, and 10 as most satisfied. Similarly, there were asked to rate the importance of each feature using a Likert Scale on five levels from 1 as "Not important" to 5 for "Very important". Since it was impossible to conduct the surveys to all e-hailing passengers', sampling was necessary to obtain a representative proportion of all passengers' [7]. Simple random sampling was used to ensure that each potential respondent within the target population stood an equal chance of being included in the sample. Two hundred questionnaires were distributed, 70 of them were returned from males, while 37 from females.

\section{RESULTS \& DISCUSSION}

In this study, the SPSS statistical version 22 was used for the data analysis to generate results. This study used descriptive analysis for respondent's profile, and correlation analysis to determine the significance level of the relationship between independent and dependent variables.

Table- I: Demographic Profile

\begin{tabular}{|l|c|c|}
\hline \multicolumn{1}{|c|}{ Variable } & Frequency (n) & Percentage (\%) \\
\hline Gender & 70 & 65 \\
Male & 37 & 35 \\
Female & & \\
\hline Age & 12 & 11 \\
Below 20 & 35 & 33 \\
$21-30$ & 32 & 30 \\
$31-40$ & 18 & 17 \\
$41-50$ & 10 & 9 \\
Above 50 & 12 & 11 \\
\hline Education Level & 58 & 54 \\
Secondary School & 28 & 27 \\
Bachelor Degree & 9 & 8 \\
Master degree & & \\
Doctor of Philosophy &
\end{tabular}

\begin{tabular}{|l|c|c|}
\hline Employement & 43 & 41 \\
Student & 27 & 25 \\
Government Servant & 16 & 15 \\
Private employee & 9 & 8 \\
Self-employment & 12 & 11 \\
Other professions & 55 & 51 \\
\hline & 34 & 32 \\
Income & 11 & 10 \\
Less than RM1500 & 7 & 7 \\
RM1501-RM3000 & & \\
RM3001-RM5000 & & \\
More than RM5000 & & \\
\hline
\end{tabular}

From the table above, total respondents are 107 and both genders participated in the study, 70 male respondents which means $65 \%$ male users of e-hailing services. Meanwhile, 37 female respondents of $35 \%$ users of e-hailing participated in this study. This indicates that the male is high using of ride-sharizng services than female. Respondents were asked to tick the age category and it has 5 age groups, the majority of age respondents are between 21-30 years old which is $33 \%$, the second age group of respondents is $31-40$ years old with $30 \%$, the third age group of respondents is $41-50$ years old which is $19.9 \%$, the fourth age group of respondents is $41-50$ years old which is $17 \%$, and the smallest group age is above 50 years old and there are 6 respondents which are only $9 \%$. This indicates that the high respondents that used the e-hailing services are from 21-30 years old.

For the education component, the majority of the education level of respondents are bachelor degree which has 58 respondents (54\%); the second group is master degree with 28 respondents (27\%), followed by secondary school with 12 respondents (11\%) and respondents with Doctor of Philosophy is the lowest at only 9 or $8 \%$. This indicates that most of the respondents that used the e-hailing services have at least bachelor degree.

Next, as can be seen in the table, employment has been divided into 5 categories such student, a government servant, a private employee, self-employment and other professions. The result indicated that most of the respondent is a student with 43 respondents or $41 \%$. It is followed by a government servant with 27 respondents (25\%). Respondent in a private employee category reported 16 respondents (15\%) and other professions reported at 12 respondents or $11 \%$. Lastly, the respondent in the self-employment category shows the lower value of 9 respondents at $8 \%$. The significant result shows that e-hailing services become a favorite transportation channel among student.

Lastly, according to Table I, the majority of the e-hailing respondent has income less than RM1500 with 55 respondent or $51 \%$ of total respondent involved in this study. The second higher is respondent who earns RM1501-RM3000 monthly with 34 respondent or $32 \%$ followed by the respondent with average income ranging RM3001-RM5000 with 11 respondents or $10 \%$ from total respondent involved. The fewest respondent used the e-hailing services has average income more than RM5000. This indicated that respondent who earns an income less than RM1500 used the e-hailing services often.

\section{A. Reliability Test}

Reliability analysis has been used in this study for the data analysis purpose. Table II shows the reliability test for the actual study for a total number of 107 respondents.

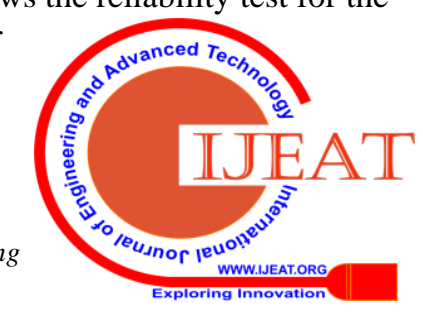


Table- II: Reliability analysis result for dependent and independent variables

\begin{tabular}{|l|c|}
\hline \multicolumn{1}{|c|}{ Variable } & Cronbach's Alpha \\
\hline Perception (PR) & 0.877 \\
\hline Trustable (TR) & 0.865 \\
\hline Comfort (CM) & 0.892 \\
\hline Promotion and Coupon Redemption (PCR) & 0.756 \\
\hline Fare (FR) & 0.718 \\
\hline
\end{tabular}

The Cronbach's values for all the variables are ranged from 0.718 to 0.892 , which means has an excellent internal consistency and it is reliable of overall items in the questionnaire. In the same way, the results obtained are categorized at an acceptable level where all the values are above $0.7[8]$.

Table III shows the level of agreement of independent variable and dependent variables. The mean for perception variable reported at 3.834 and the standard deviation of 0.629 . Besides that, the mean for the trustable variable is 3.821 and the standard deviation of 0.638 . The mean for comfort is 3.990 with the standard deviation of 0.771 . Apart from that, the mean for promotion and coupon redemption is 3.712 and standard deviation of 0.611 . Lastly, the mean for fare is 3.818 and standard deviation of 0.652 . The result indicates that the level of agreement for all variables is agreed.

Table- III: The level of agreement of independent variable and dependent variables

\begin{tabular}{|c|c|c|c|}
\hline Variable (average) & Mean & Standard Deviation & Level of agreement \\
\hline Perception (PR) & 3.834 & 0.629 & Agree \\
\hline Trustable (TR) & 3.821 & 0.638 & Agree \\
\hline Comfort (CM) & 3.990 & 0.771 & Agree \\
\hline Promotion and Coupon Redemption (PCR) & 3.712 & 0.611 & Agree \\
\hline Fare (FR) & 3.818 & 0.652 & Agree \\
\hline
\end{tabular}

\section{B. Correlation Analysis}

The correlation analysis in Table IV shows that perception and comfort have a strong relationship with the degree of determination 0.823. Besides, the relationship between the trustable variable and the comfort variable is also high at 0.812. This significant result clearly shows that factor that related to comfort produced high degree of determination. This is proved by the relationship between comfort and promotion and coupon redemption with the degree of determination of 0.802 . However, the relationship between promotion and coupon redemption (PCR) with fare were marginally low at 0.619 . Such low percentages cannot be the sole reason for discounting the factor from the statistical investigation. This is due to the fact that both variables do attribute to the overall performance of the study.

Table- IV: Correlation among Variables

\begin{tabular}{|c|c|c|c|c|c|}
\hline Variable & PR & TR & $\mathbf{C M}$ & PCR & FR \\
\hline Perception (PR) & 1.000 & 0.788 & 0.823 & 0.692 & 0.711 \\
\hline Trustable (TR) & & 1.000 & 0.812 & 0.650 & 0.792 \\
\hline Comfort (CM) & & & 1.000 & 0.633 & 0.802 \\
\hline Promotion and Coupon Redemption (PCR) & & & & 1.000 & 0.619 \\
\hline Fare (FR) & & & & & 1.000 \\
\hline
\end{tabular}

\section{CONCLUSION}

A Based on this study, there are several conclusions that can be made. First, through Reliability analysis, all variables show satisfactory results. This clearly shows that all the variables studied influence the selection of e-hailing adoption with the highest results recorded by comfort level. Secondly, through the mean and standard deviation, all variable shows the highest level of agreement. Therefore, as a conclusion, this study is seen to be beneficial to e-hailing service operators as they will know the important factors that influence the user to choose the service. In the same way, service operators can improve their services in order to achieve customer satisfaction. In addition, investigation on how the other external factors such as service quality and technology used should take into account in future which may have a positive impact on the adoption of e-hailing applications.

\section{ACKNOWLEDGMENT}

The authors would like to thank Center for Diploma Study, Universiti Tun Hussein Onn Malaysia, and also the Ministry of Higher Education Malaysia, for their grant awarded to conduct this research through TIER 1 Grant Vot. H152.

\section{REFERENCES}

1. Govender, K. (2014). Public Transport Service Quality in South Africa: A Case Study of Bus and Min Bus Services in Johannesburg. African Journal of Business Management. 8(10) 317-326.

2. Kumar P.K., \& Kumar N.R. (2016). A Study On Factors Influencing the Consumers in Selection of Cab Services, International Journal of Social Science and Humanities Research, Vol. 4, Issue 3, Pp: (557-561).

3. Horsu E.N. \& Yeboah S. T. (2015). Influence of Service Quality on Customer Satisfaction: A Study of Minicab Taxi Services in Cape Coast, Ghana. International Journal of Economics, Commerce and Management. Vol. III, Issue 5 Pp. 1-14.

4. Ilma Khairani and Sri Rahayu Hijrah Hati. (2017). The Effects of Perceived Service Quality towards Customer Satisfaction and Behavioral Intentions in Online Transportation. International. Journal of Humanities and Management Sciences (IJHMS) Volume 5, Issue 1, Pp. 1-5.

5. Khuong M. N., \& Dai N. Q. 2016. The Factors Affecting Customer Satisfaction and Customer Loyalty — A Study of Local Taxi Companies in Ho Chi Minh City, Vietnam. International Journal of Innovation, Management and Technology, Vol. 7, No. 5.

6. Hong Z.L.Y. \& Zhang Z. (2017). An Empirical Analysis of On Demand Ride-Sharing and Traffic Congestion: Proceedings of The 50th Hawaii International Conference On System Sciences.

7. Litman, T. (2008). Valuing Transit Service Quality Improvements," Journal of Public Transportation, P.43-64. 
8. Sumaedi S.I, Bakti G. M. Y., \& Yarmen M. (2012). The Empirical Study of Public Transport Passengers' Behavioral Intentions: The Roles of Service Quality, Perceived Sacrifice, Perceived Value, And Satisfaction (Case Study: Paratransit Passengers in Jakarta, Indonesia), International Journal for Traffic And Transport Engineering, 2(1): 83 97.

\section{AUTHORS PROFILE}

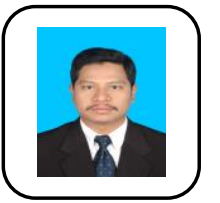

Salman Salim, served as Industrial Fellow in the Department of Civil Engineering at Centre Diploma Studies (CeDS), University Tun Hussien Onn Malaysia (UTHM) with 15 years of experience teaching and writing in construction engineering also more than 10 years' experience in construction project from related industry. The academic qualification starting from Certificate Ungku Omar Polytechnic Ipoh Malaysia (Land Survey, 1988), Diploma in Civil Engineering University Technology Malaysia (1998), Bachelor with honors in Civil Engineering University Technology Malaysia (2001), and Master in Civil Engineering from UTHM (2012). He managed to get 5 research grants and produced 24 learning modules. He also managed to publish 7 book chapter, 4 proceeding paper, 2 book and 2 international journal papers. He is also registered as a member of the graduated engineer to the Board of Engineers Malaysia (BEM), Institute of Engineers Malaysia (IEM), Malaysia Board of Technology (MBOT), Concrete Association of Malaysia and Malaysia Bamboo Society (MBS). He is recognized as a Professional Technologist (Ts) from MBOT since 2017 under the field of Building Construction Technology.

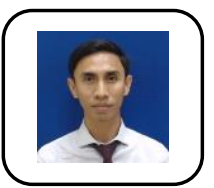

Mohamad Azim Mohammad Azmi, The author was born on June 18, 1988, in Ipoh, Perak, Malaysia. He received his earliest education at Sekolah Kebangsaan Tanjung Rambutan, Ipoh from 1995 until 2000. He later went to Sekolah Menengah Kebangsaan Tanjung Rambutan, Ipoh Perak, for his secondary school from 2001 to 2005. Then, after receiving excellent SPM result, He attended Polytechnic Ungku Omar, Ipoh Perak for Diploma program in Civil Engineering. After successful graduated his Diploma in 2009, He pursued his degree at the Universiti Tun Hussein Onn Malaysia, and graduated with the Bachelor of Engineering (Hons) in Civil Engineering in 2013. Upon graduation, he then enrolled in the Master's program in Civil engineering at the same university. As a graduate researcher's student, the author worked under supervisor Associate Professor Dr. Saiful Azhar bin Ahmad Tajudin on a variety of research assignments. He was involved in research project headed by Associate Professor Dr. Saiful Azhar bin Ahmad Tajudin such as soil remediation using Electrokinetic, stabilisation and solidification of contaminated soil using cement and many geotechnical projects. He also active in conducting research from others civil engineering field like structural and transportation. He was graduated his Master degree in Civil Engineering in 2015 and pursued his study in Doctor of Philosophy level in Civil Engineering at the same university and successful graduated in 2019. The author is currently started a career as a civil engineering lecturer in Department of Civil Engineering, Center for Diploma Studies, Universiti Tun Hussein Onn Malaysia.

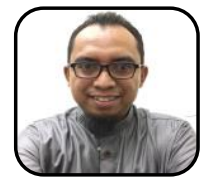

Ts. Mohd Erwan Sanik, is a Masters holder in Civil Engineering with specialty in the Highway and Traffic Engineering niche area. He graduated from Universiti Sains Malaysia in the year 2000 (Bachelor of Engineering) and 2007 (Master of Science). Since 2007, he has been involved in publication of more than 35 journal and proceeding articles, books and book chapters as main- and co-authors in various Civil Engineering areas. Of these, 17 are SCOPUS indexed articles. He has been also involved in many researches starting from 2003 (as research officer) until now. Since 2009, he has involved in 22 research grants as main and co-researcher, funded by the Universiti Tun Hussein Onn Malaysia (UTHM) and Malaysian Ministry of Education. He is a Graduate member of Malaysian Board of Engineering (BEM), Malaysian Board of Technologies (MBOT), and Road Engineering Association of Malaysia (REAM). Membership in REAM automatically made him a member of the Road Engineering Association of Asia and Australasia (REAAA). He has been recognized as a Professional Technologist (Ts) from MBOT since 2018 under the field of Transportation and Logistics Technology. He is currently holding a post as Industry Fellow in UTHM and also the Head of the Spatial Investigation of Civil Engineering (SpICE), a research focus group at the Centre for Diploma Studies (CeDS).

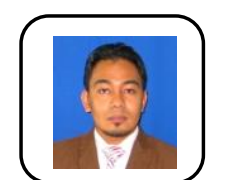

Ahmad Hakimi Mat Nor, is a Masters holder in Civil Engineering, specialty in Geotechnical Engineering on soft soil. He graduated from Universiti Tun Hussein Onn Malaysia in the year 2008 (Bachelor of Civil Engineering) and 2012 (Master of Civil Engineering). Since 2014, he has been involved in publication of more than 25 journal and proceeding articles, books and book chapters as mainand co-authors in various Civil Engineering areas. Of these, 6 are SCOPUS indexed articles. He has been also involved in many researches starting from 2009 (as instructor engineer) until now. Since 2009, he has involve in 8 research grants as main- and co-researcher, funded by the Universiti Tun Hussein Onn Malaysia (UTHM). He is a Graduate member of Malaysian Board of Engineering (BEM), and Malaysian Board of Technologies (MBOT). He is currently holding a post as Industrial Fellow in UTHM and keep on fully dedicating in teaching, supervising, research and publication for the sake of current and future generation.

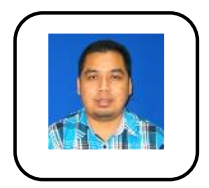

Mohamad Hairi bin Osman, served as Industria Fellow in the Department of Civil Engineering Technology at Faculty of Engineering Technology, Universiti Tun Hussein Onn Malaysia (UTHM) with 11 years of teaching experiences and he also was involved in construction industry around 4 years. The academic qualification starting from Bachelor with honors in Civil Engineering (Construction) Universiti Tun Hussein Onn Malaysia (2006), and Master in Civil Engineering from the same university (2012). He managed to get 3 research grants and produced 6 learning modules. He also managed to publish 9 book chapter, 7 proceeding paper and 5 international journal papers. He is also registered as a member of the graduated engineer to the Board of Engineers Malaysia (BEM), Institute of Engineers Malaysia (IEM), Malaysia Board of Technology (MBOT), Concrete Association of Malaysia and Malaysia Bamboo Society (MBS). He is also registered as a Professional Technologist (Ts) qualified by MBOT since 2017 and registered as Professional Engineer (Ir) qualified by BEM since 2015. 